\author{
Marko Golnar \\ E-mail: marko.golnar@fpp.uni-lj.si \\ Bojan Beškovnik \\ E-mail: bojan.beskovnik@fpp.uni-lj.si \\ University of Ljubljana, Faculty of Maritime Studies and Transport \\ Pot pomorščakov 4, 6320 Portorož, Slovenia
}

\title{
Green Maritime Transport as a Part of Global Green Intermodal Chains
}

\begin{abstract}
Environmental pollution is increasingly becoming a major global problem. Consequently, companies and policy makers are facing mounting pressure to reduce their impacts of logistics activities and make transport greener. The challenge to reduce the carbon intensity of maritime transport is even more important when we take into equation the fact that carries about $90 \%$ of the world trade. While car industry has already taken actions to greener cars, maritime industry is subject to fewer regulations and slower progress. This article overviews upcoming trends of green intermodal chains, initiatives in green maritime transport and how noteworthy is share of their impact in the transport chain as a whole. Speed reduction is one of most important measures which can be implemented right away with win-win impacting on environment and fuel cost. The study analysis environmental impacts of different services to eastern Adriatic ports, with special emphasis of slow steaming impacts on pollution level. The paper exposes that direct lines with bigger ships cause lower emissions of $\mathrm{CO}_{2}, \mathrm{NO}_{\mathrm{x}}$ and $\mathrm{SO}_{\mathrm{x}}$ and that with decisions of slow steaming the pollution level decreases significantly.
\end{abstract}

Keywords: decarbonisation, intermodal transport chains, maritime, carbon dioxide, slow steaming

\section{Introduction}

With the globalization of supply chains, the distance between nodes in distribution network has grown considerably. Longer distances lead to increased emissions on the transportation routes, resulting in an inflated carbon footprint. Although, international shipping plays an essential role facilitating the global economy with over $80 \%$ of global trade by volume and more than $70 \%$ of global trade by value which is carried over the sea [1] emissions produced in connection with international shipping are expected to increase significantly. Between the years 1950 and 2004, international trade has grown with average rate of 5,9\% per annum [2]. These are carried by approximately $94 \%$ of 
the world fleet ships, while the remainder is occupied with the transport of passengers and other functions [3]. Maritime shipping is primarily powered by fuel which results in high GHG emissions. During aforementioned period total shipping emissions arose to approximately 950 million tons of $\mathrm{CO}_{2}$ and of $\mathrm{CO}_{2} \mathrm{e}$ of GHGs in 2012 [4], which presents the same amount as those emitted in Germany or from entire aviation sector [5]. Greenhouse gas (GHG) emissions increase global temperatures, which presents one of the most serious environmental issues specially because of the negative effect on ecosystems and people. Thus their growth should be mitigated and monitored from legal authorities. Over the past few years there have been several international conferences on environmental protection studying GHG emissions from maritime shipping. At the Paris agreement parties have agreed on setting the goal of limiting global warming to well below $2^{\circ} \mathrm{C}$ in order to achieve the long term temperature goal from pre-industrial levels which will demand to at least half the worldwide emissions from the 1990 by the 2050 [6].

International shipping generated around 3\% of global $\mathrm{CO}_{2}$ emissions in 2012. By the predictions in IMO Third GHG report [4], shipping emissions could increase from $50-250 \%$ by 2050 if no further measures would be implemented. Therefore, those unmitigated emissions could reach $10-25 \%$ of global emissions as other sector decarbonize. While Paris Agreement on accepting measures for mitigating global warming has been accepted by the parties of the United Nations Framework on Climate Change Convention, it has to be mentioned that main emitters like shipping and aviation sector are not explicitly included in the document, instead there are countries commitments towards certain goals. Another document managing regulation of greenhouse gas emissions from international maritime shipping without setting legally binding targets on sectoral emissions is Kyoto protocol. More stringent steps towards GHG reduction requirements from maritime transport were formulated at the $72^{\text {nd }}$ meeting of Marine Environment Protection Committee (MEPC) with a roadmap on GHG emission reduction pathway of "at least" $50 \%$ on 2008 levels by 2050 with a clear target to fully decarbonize by $100 \%$ by 2050 , if possible.

To facilitate reduction goals of roadmap, IMO introduced EEDI (Energy efficiency design index) and EEOI (Energy Efficiency Operational indicator) standards which came into force in 2013. While EEDI is expected to stimulate continuous innovation on $\mathrm{CO}_{2}$ reduction and technical development from scratch, EEOI sets a minimum energy efficiency level per capacity mile - an approach for shipping companies to effectively manage ship fleet over time as monitoring tool. Thus, this tool also urges ship owner and operator at each stage to consider implementation of new technologies when looking up on new way to optimize the performance of a ship.

Different academic literature focuses on measures of reducing GHG emissions from maritime shipping and GHG emission evaluation and calculation. However, not much research has been done on maritime shipping GHG emission in Adriatic ports area and what is the impact of actual services and operating vessels on local ecosystem. Consequently, the paper addresses the following research goals: (1) analyze advantages 
and disadvantages of slow steaming in Adriatic area, (2) make a quantitative description of relationship between direct and indirect voyages with different slow steaming scenarios, (3) highlighting the most "green" solution of maritime service to serve intermodal chains from Asia to eastern Adriatic market.

\section{Literature background}

In recent years' climate change has become one of the major global environmental problems specially because of negative impacts on human health and natural environment [7], [8]. One of the most typical form of climate change is global warming which is caused by greenhouse gas emissions. Typical form of climate change is greenhouse gas [9]. Although that GHG emissions in transport sector has started to be regulated in road sector with EURO norms back in nineties, GHG emissions from marine shipping hasn't gained enough attention from environmentalists and political authority to be regulated in similar direction. There are enormous emissions of GHG emitted from shipping every year and the main substances are coming from combustion of marine fuels. GHG emissions form shipping presents approximately $1,1 \mathrm{Gt}$ of carbon dioxide, as well as 2,3 Mt of sulphur dioxide and 3,2 Mt nitrogen oxides per year. The greatest emitters in marine shipping are long hauls especially international and intercontinental journeys [4]. Quantity of emissions is partly dependent on fuels used as different fuels produce a various proportion of GHG emissions [10]. With ambitious demand for shipping in the future GHG emission will grow consequently. At the moment qualitative and quantitative measures for cutting down GHG emissions have been the focus of research in order to increase impact on environmental protection. As one of the economic measures higher price of fuel has been presented as a tool to reduce GHG emissions. Other studies suggested emission taxes and emission regulations [11]. In order to meet IMO target values for 2030 and 2050 some studies suggested the use of alternative fuel as LNG or methanol fuel. It has been concluded that using methanol fuel would reduce $\mathrm{NO}_{\mathrm{x}}, \mathrm{SO}_{\mathrm{x}}, \mathrm{CO}, \mathrm{CO}_{2}$, and $\mathrm{PM}$ emissions by $76,78 \% ; 89 \% ; 55 \% ; 18,13 \%$ and $82,56 \%$ respectively [12]. Although change to alternative fuels results in more clean exhaust, the cost of engine conversion is high with longer depreciation time. Therefore, a variety of ship propulsion technologies can reduce GHG shipping emissions but they face innovation barriers, which in most of the time limit their broader dissemination. Other alternatives include bio-fuels, hydrogen, electric propulsion or even nuclear fuels. In addition, each alternative fuel provides different decarbonisation levels and experience different economic costs as well as various air pollution reductions. Various efficiency measures exist that would reduce the fuel consumption per unit distance, particularly the act of slow steaming. Thus, their impact on efficiency depends on various factors such as the class of vessel and its application. In other hand one of the soft measures have appeared organically when shipping companies have slowed down ships speed in order to slash cost during the economic crisis, which indirectly reduced GHG emissions 
from marine shipping [13]. On this basis, several academic works have been focusing on optimization speed vs. shipping cost. In this way Corbett et al. [14] have developed a ship speed optimization model which maximizes carrier's voyage profitability and minimizes the carriers voyage $\mathrm{CO}_{2}$ emissions. Furthermore, Cariou and Cheaitou [15] have established a model which govern optimal ship speed in order to maximize the carrier's voyage profitability and minimizes carrier's voyage $\mathrm{CO}_{2}$ emissions according to speed limit and fuel tax policies. In addition, Wong et al. [16] developed a similar model which additionally considers delays, while Fagerholt et al. [17] proposed a Mixed Integer Linear Programming Model (MILP) to decide on vessel's optimal slow steaming speed which minimizes vessel's fuel costs and at the same time suits strict limits of emissions control areas(ECAs). In general, impacts of slow steaming since 2008 showed that container ships have reduced carbon emission by $11 \%$ [18].

\section{Material and methods}

The research aims to find the answer on how the operational policy of transport process is reflected on sustainable operations. The research is based on the analysis of the following sets of data:

- what's the impact of maritime transport on main transport route from Asia to different eastern Adriatic ports from environmental pollution perspective,

- how much the speed of ship affects the elements of environmental pollution if ship is operating at full speed and at slow-steaming speed.

The analysis is performed on an important transport route from Asia to Europe, using the southern transport route via the eastern Adriatic ports Bar, Ploče, Rijeka and Koper. The analysis of the environment pollution from transport chain covers 5 important overseas transport routes. In total 5 services and connections from Chinese port Shanghai are analyzed. Namely, from Shanghai a direct and indirect services are operational, offering different basis for intermodal chains from time perspective and slot availability. Ocean services of three global container carriers (COSCO, HapagLloyd and MSC) are analyzed, where their frequency of departure and port of discharge (POD) calls are compared, as well as their transit times and transshipment ports in Mediterranean (MED) area.

The EcoTransIT World calculator is used to calculate environmental pollution from transport activities and energy efficiency of the intermodal chain. There are other environmental calculators on the marker, such as: NTMCalc and DHL Carbon calculator. The EcoTransIT calculator basis on the EN 16528 standard guidelines (Methodology for calculation and declaration of energy consumption and greenhouse gas emissions of transport services) and is a useful tool for the transport industry. The following parameters were used in the calculation: container weight $14 \mathrm{t} / \mathrm{TEU}$, ship occupancy $70 \%$, normal ship speed and reduced shipping speeds for $10 \%, 20 \%$ and $30 \%$. Ship type used is container vessel on Suez trade which has in default speed of 
$30,2 \mathrm{~km} / \mathrm{h}$. Focus of analysis was only the port-port maritime transport, without inland transport and manipulation of cargo or container at POL and POD.

\section{Results}

The analysis of the total intermodal transport time (TT) from Asia to Central Europe shows a slight but meaningful difference in the timing between direct and indirect transport service. Both carriers, COSCO and MSC operate direct service on Asia-Adriatic transport route and feeder service from hub transshipment port in MED area. On the other hand, Hapag-Lloyd offers just feeder connections to analyzed 4 Adriatic ports. All carriers have at least weekly departures from Asian ports, where COSCO and MSC have even more calls on weekly basis as they can load containers on direct service or via feeder connection.

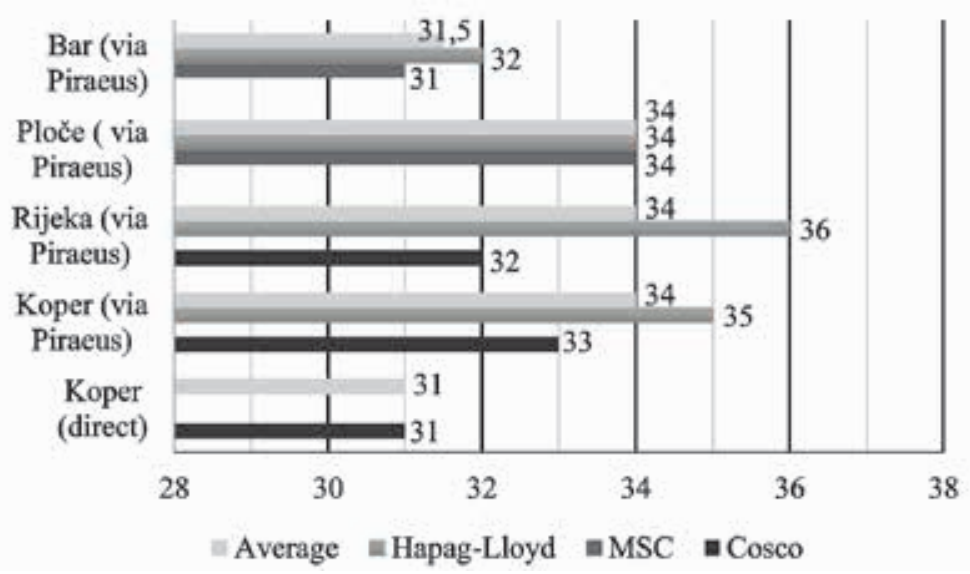

Figure 1: Transportation times of different shipping providers (in days)

The analysis shows minimal difference in TT between direct and indirect service. The average travel time of all 4 ports is 32 days. The direct transport of a container from Shanghai to Koper is 31 days, while indirect service through transshipment port Piraeus vary from 33 - 35 days (Figure 1). Similar transport times of indirect transport services can be found for Rijeka (via Piraeus), Ploče (via Piraeus) and Bar (via Piraeus) with 32-36, 34 and 31-32 days respectively. Therefore, the difference between the shortest and the longest transport service is approximately $15 \%$ of the total transit time. Although the port of Bar is at the very entrance to the Adriatic Sea the TT compared to Koper or Rijeka on direct service is at the same level.

In table 1comparison have been made for normal operating speed $(30 \mathrm{~km} / \mathrm{h})$ and reduced speed (RS) for 10\%, 20\% and 30\% (TT-Reduced Speed \%). Including manipulation and times of customs services at ports, which usually takes from 1-2 days, 
can be concluded that most of the shipping companies nowadays use $20 \%$ reduction speed on their voyages.

Table 1: Different transit times at various speed reduction:

\begin{tabular}{|c|c|c|c|c|c|}
\hline & $\begin{array}{c}\text { Distance } \\
{[\mathrm{km}]}\end{array}$ & $\begin{array}{c}\text { Transit time } \\
-\mathrm{RS} 0 \% \\
{[\mathrm{Day}]}\end{array}$ & $\begin{array}{c}\text { Transit } \\
\text { time- } \\
\text { RS10\% } \\
{[\text { Day }]}\end{array}$ & $\begin{array}{c}\text { Transit time- } \\
\text { RS20\% } \\
{[\text { Day }]}\end{array}$ & $\begin{array}{c}\text { Transit time- } \\
\text { RS30\% [Day] }\end{array}$ \\
\hline $\begin{array}{c}\text { Koper } \\
\text { (direct) }\end{array}$ & 15.699 & 21,7 & 24,1 & 27,1 & 30,9 \\
\hline $\begin{array}{c}\text { Koper (via } \\
\text { Piraeus) }\end{array}$ & 15.972 & 22,0 & 24,5 & 27,5 & 31,5 \\
\hline $\begin{array}{c}\text { Rijeka (via } \\
\text { Piraeus) }\end{array}$ & 15.917 & $22, .0$ & 24,4 & 27,5 & 31,4 \\
\hline $\begin{array}{c}\text { Ploče (via } \\
\text { Piraeus) }\end{array}$ & 15.629 & 21,6 & 24,0 & 27,0 & 30,8 \\
\hline $\begin{array}{c}\text { Bar (via } \\
\text { Piraeus) }\end{array}$ & 15.386 & 21,2 & 23,6 & 26,5 & 30,3 \\
\hline
\end{tabular}

Comparison of different northern Adriatic ports reveals differences in the level of pollution and energy efficiency of the transport process. Using the EcoTransITWorld calculator, indicates that direct service consume 2\% less energy, emits $2 \%$ less $\mathrm{CO}_{2}$ and GHG emissions as $\mathrm{CO}_{2 \mathrm{e}}, 2,2 \%$ less $\mathrm{NO}_{\mathrm{x}}$ emissions, 1,7\% less Non-methane hydrocarbon (NMHC) emissions, $1,7 \%$ less $\mathrm{SO}_{2}$ emissions and 1,7\% less PM emission. Direct service is also $2 \%$ more energy efficient than indirect one, with transshipment in MED.

On top of that any extra transshipment manipulation at indirect transport service require extra $2 \mathrm{MJ}$ of energy used for every container move (load/unload) at transshipment port. Further inspection of indirect transport services to Koper, Rijeka, Ploče and Bar reveals that level of pollution increases with the distance. Therefore, transport to Bar which is the closest port from Piraeus is the most energy efficient and emits less emissions as transport service to Koper which is the most distant from ports considered. However, it can be concluded that shipping missions are explicitly distance related.

Comparing data of direct service to Koper with other indirect services reveals that consumes same amount of energy and emits same amount of pollutants as indirect service to port Ploče, which is $490 \mathrm{~km}$ closer from Shanghai than Koper. 

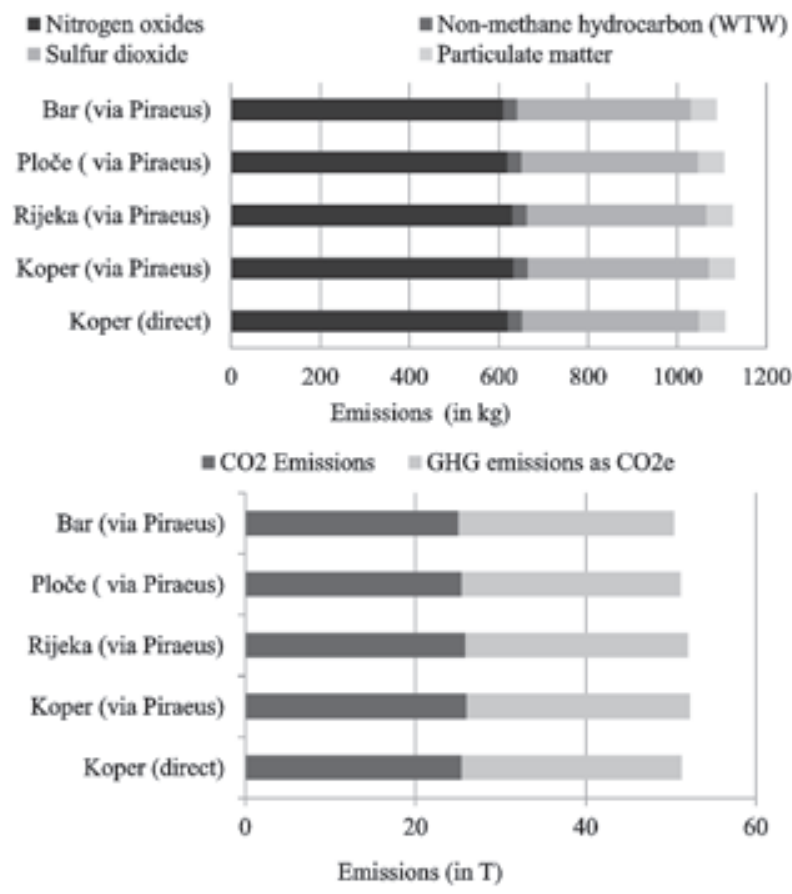

Figure 2: Pollutants emitted of compared routes

The analysis of slow-steaming scenarios with reduction of speed for $10 \%, 20 \%$ and 30\%highlights important reduction of pollution level by lowering the average travel speed. Namely, at reduction of $10 \%$ of speed $21,1 \%$ less energy is used and $20,7 \%$ less $\mathrm{CO}_{2}$ emissions and $\mathrm{GHG}$ emissions as $\mathrm{CO}_{2} \mathrm{e}$ are produced. Almost the same reduction is with $\mathrm{NO}_{\mathrm{x}}$ and $\mathrm{NMHC}$ emissions $(-21,3 \%), 20,7 \% \mathrm{SO}_{\mathrm{x}}$ emissions $(-20,7 \%)$ and $\mathrm{PM}$ emissions (-21\%).

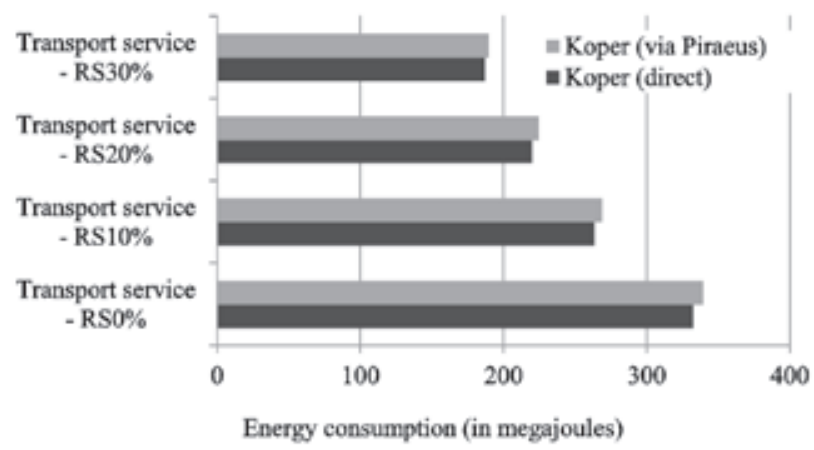

Figure 3: Comparison of energy consumption at different speed reductions on transport route Shanghai - Koper vs. Shanghai - Koper (via Piraeus) 
Furthermore, increasing reduction of speed for $20 \%$ brings $33,8 \%$ reduction of energy used, $33,9 \%$ less $\mathrm{CO}_{2}$ and $\mathrm{GHG}$ emissions as $\mathrm{CO}_{2} \mathrm{e}, 35 \%$ less $\mathrm{NO}_{\mathrm{x}}$ and $\mathrm{NMHC}$, $33,8 \%$ less $\mathrm{SO}_{2}$, and $34,3 \%$ less PM emissions. Another $10 \%$ reduction in speed of container ship results in $43,8 \%$ less energy used, $44 \%$ less $\mathrm{CO}_{2}$ emissions and GHG emissions as $\mathrm{CO}_{2} \mathrm{e}, 45,8 \%$ less $\mathrm{NO}_{\mathrm{x}}$ emissions, $45,7 \%$ less Non-methane hydrocarbon, $44 \%$ less $\mathrm{SO}_{2}$ emissions and $44,7 \%$ less $\mathrm{PM}$ emissions.

\section{Discussion}

The combination of five intermodal transport options from Shanghai to northern Adriatic ports with different shipping services demonstrates different decision options that transport carriers' takes, trying to fulfil customer needs on delivery time cost and pollution. The comparison points out that the best choice to transport 20' container by sea is direct service from port of loading in Shanghai to port of discharge in Koper without any transshipment stops. Such a transport is $2 \%$ more greener (less $\mathrm{CO}_{2}$, GHG emissions as $\mathrm{CO}_{2 \mathrm{e}}, \mathrm{NO}_{\mathrm{x}}, \mathrm{NMHC}, \mathrm{SO}_{2}$ and $\mathrm{PM}_{10}$ ) than indirect services. At the same time this service is on average $10 \%$ faster and eliminates eventual further TT prolongation due to operational problems in transshipment port. Although the transport route to southern Adriatic ports is shorter, these services produce the same amount of GHG emission as direct services to northern Adriatic ports, predominantly due to smaller feeder vessels.

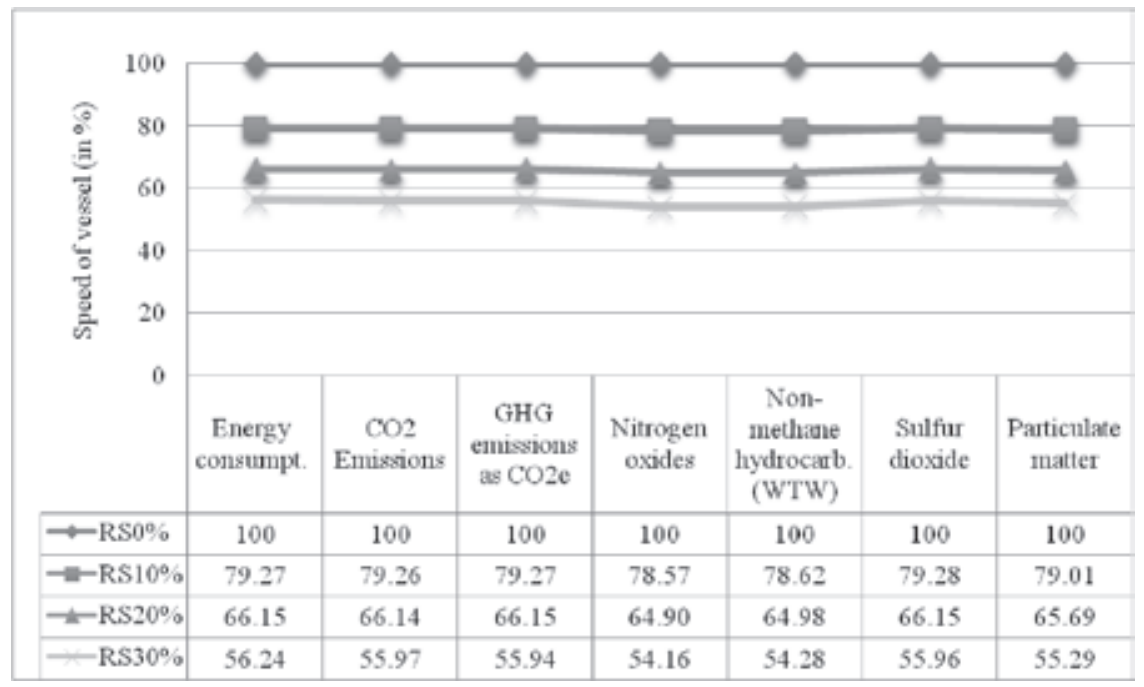

Figure 4: Comparison of emissions at different speed reductions of vessel on Shanghai-Koper transport route 
Meanwhile research reveals that transport carriers nowadays drive at $20 \%$ reduced speed mostly to retain competitiveness on market and to fulfil more and more stringent air pollution regulations in order to global climate change mitigation and adaptation. According to EcoTransITWorld calculations reduction of speed for $20 \%$ reflects in approximately $34 \%$ lower energy consumption, $\mathrm{CO}_{2}$, GHG emissions as $\mathrm{CO}_{2 \mathrm{e}}, \mathrm{NO}_{\mathrm{x}}$, $\mathrm{NMHC}, \mathrm{SO}_{2}$ and particulate matter (Figure 4). In order to meet target from IMO's initial agreement in 2018 to reduce $\mathrm{GHG}$ emissions by $50 \%$ by 2050 compared to 2008 emissions more stringent measures needs to be adopted, because carriers cannot further reduce travel time, as this would influence the supply chain reliability and transfer of costs to end users of maritime transport.

One of the bold actions to clean up shipping emissions is to reduce the Sulphur content in ships' fuel oil. The regulation for controlling environmental impacts from shipping Maritime Agreement Regarding Oil Pollution (MARPOL) for $\mathrm{SO}_{\mathrm{x}}, \mathrm{NO}_{\mathrm{x}}$ and GHG emissions is originally focusing on limiting Sulphur content in bunker fuel to $4,5 \%$. The global sulphur content in ships fuel oil is set to be reduced substantially in 2020 from $3,50 \%$ to $0,50 \%$. Drastically drop in overall $\mathrm{SO}_{\mathrm{x}}$ emissions from ships will prevent acid rain, which reflects in less harm to crops, forests and aquatic species and ocean acidification.

Present paper highlights the need of transparent information about green maritime transport that is offered to shippers and consignees, because by their choices of an appropriate service they indirectly influence the level of pollution in certain area. These data are especially important in complex transport chains where all selected ports could be an option as intermodal node. Namely, by knowing how different transport operators perform current intermodal transport gives significant information where it can be improved to meet future emissions limits.

\section{Conclusions}

Green maritime transport within green supply chain is gradually becoming systematically regulated. This paper studies relationship between maritime GHG emissions and speed reduction of voyages which organically appeared during the financial crisis in 2008 when companies reduced the cost by slowing down navigation speed, energy conservation and putting ships in idle status and do it so indirectly reducing GHG emissions. However, the study of ocean services to eastern Adriatic reveals that nowadays most of shipping operators use slow-steaming with reducing speed for $20 \%$, while reducing GHG emissions for $34 \%$. It has been also shown that direct service is $2 \%$ more energy efficient and pollutes $2 \%$ less than indirect service. Undoubtedly, it is very important from the environmental perspective that carriers use slow-steaming as presently they reduce pollution in Adriatic area up to $40 \%$, although this has negative influence on supply chain responsiveness. Namely, by slow-steaming approach the TT from Asian markets is prolonged for 10 to $20 \%$. 
The research exposes that further research is still needed in the area of introduction of new standardized approaches, which are key tools to informing stakeholders and end buyers on level of green transport. Nowadays models for selecting and evaluating transportation services are mostly based on the price/time ratio while there are missing environmental impact information. Current paper will serve for further research on the field of implementation and evaluation on levels of green transport as well on the other hand as basis for models for more efficient decision making intermodal transport solution.

\section{Acknowledgements}

The study is part of a bilateral project between Slovenia and Montenegro under the name "The development of intermodal transport, intermodal nodes and hinterland network in the eastern Adriatic region".

\section{References}

1. U. N. C. T. A. D.: DEVELOPMENT, REVIEW OF MARITIME TRANSPORT 2016. Place of publication not identified: UNITED NATIONS, Geneva 2016.

2. HUMMELS, DAVID: ,,Transportation Costs and International Trade in the Second Era of Globalization", Journal of economic perspectives, AEA Publications 2007

3. U. N. C. T. A. D.: ,, United Nations Conference on Trade and Development, Review of maritime transport 2017", Place of publication not identified, Geneva 2017.

4. SMITH, TRISTAN: ,, Third IMO GHG Study 2014: Executive Summary and Final Report”, Place of publication not identified, International Maritime Organization (IMO) 2015

5. INTERNATIONAL ENERGY AGENCY; ,,CO2 Emissions from Fuel Combustion 2016”, OECD Publishing 2016.

6. UNITED NATIONS: ,, Report of the Conference of the Parties on its twenty-first session, held in Paris from 30 November to 13 December 2015", United nations 2016.

7. BARBULESCU, ALINA: ,, Mathematical modeling of sulfur dioxide concentration in the western part of Romania" Journal of Environmental Management, Elsevier 2017.

8. WOERD, FRANS VAN DER: „The business of climate change: corporate responses to Kyoto”, Greenleaf Pub 2005.

9. BERGQUIST, PARRISH: „Does Global Warming Increase Public Concern about Climate Change?" The Journal of Politics, The university of Chicago press journals 2019.

10. BALCOMBE, PAUL: „How to decarbonise international shipping: Options for fuels, technologies and policies", Energy Conversion and Management, Elsevier. 2019

11. TSENG, PO HSING: „Exploring the viability of an emission tax policy for ships at berth in Taiwanese ports", International Journal of Shipping and Transport Logistics, Inderscience publishers 2016.

12. AMMAR, NADER R.: ,,An environmental and economic analysis of methanol fuel for a cellular container ship", Transportation Research Part D: Transport and Environment, Elsevier 2019.

13. MEYER, JASPER: „,Slow Steaming in Container Shipping”, 2012 45th Hawaii International Conference on System Sciences, Institute of Electrical and Electronics Engineers (IEEE) 2012

14. J. J. CORBETT, JAMES J.: ,, The effectiveness and costs of speed reductions on emissions from international shipping” Transportation Research Part D: Transport and Environment, Elsevier 2009. 
15. CARIOU, PIERR: „, The effectiveness of a European speed limit versus an international bunkerlevy to reduce CO2 emissions from container shipping", Transportation Research Part D: Transport and Environment, Elsevier 2012.

16. WONG, EUGENE Y.C: ,,An utility-based decision support sustainability model in slow steaming maritime operations", Transportation Research Part E: Logistics and Transportation Review, Elsevier 2015.

17. FAGERHOLT, KJETIL: ,Maritime routing and speed optimization with emission control areas”, Transportation Research Part C: Emerging Technologies, Elsevier 2015.

18. CARIOU, PIERRE: „Is slow steaming a sustainable means of reducing CO2 emissions from container shipping?", Transportation Research Part D: Transport and Environment, Elsevier 2011. 
